九州大学学術情報リポジトリ

Kyushu University Institutional Repository

\title{
Variations in the Expression of Photosynthesis- Related Proteins in Field Chattonella Marina Cells During a Harmful Algal Bloom
}

Qiu, Xuchun

Laboratory of Marine Environmental Science, Faculty of Agriculture, Kyushu University

Mukai, Koki

Laboratory of Marine Environmental Science, Faculty of Agriculture, Kyushu University

Shimasaki, Yohei

Laboratory of Marine Environmental Science, Faculty of Agriculture, Kyushu University

Tsuyama, Michito

Laboratory of Silviculture, Faculty of Agriculture, KyushuUniversity | Laboratory of Marine Environmental Science, Faculty of Agriculture, Kyushu University

他

https://doi.org/10.5109/1854009

出版情報: 九州大学大学院農学研究院紀要. 62 (2)，pp.373-380，2017-09-08. Faculty of Agriculture, Kyushu University

バージョン :

権利関係 : 


\title{
Variations in the Expression of Photosynthesis-Related Proteins in Field Chattonella Marina Cells During a Harmful Algal Bloom
}

\section{Xuchun QIU*, Koki MUKAI, Yohei SHIMASAKI, Michito TSUYAMA', Tadashi MATSUBARA ${ }^{2}$, Takashi NAKASHIMA ${ }^{3}$, Hirofumi ICHINOSE ${ }^{4}$, Yu NAKAJIMA ${ }^{5}$, Tsuneo HONJO ${ }^{6}$ and Yuji OSHIMA}

\author{
Laboratory of Marine Environmental Science, Faculty of Agriculture, Kyushu University, \\ Fukuoka 812-8581, Japan \\ (Received April 28, 2017 and accepted May 10, 2017)
}

\begin{abstract}
Time series variations in protein expression profiles in field Chattonella marina cells were investigated during a HAB occurred in the inner part of Ariake Sea, Japan (5-14 September, 2012). This study aimed to gather information on the molecular mechanisms underlying the physiological responses in field C. marina population during HAB. Proteomic analysis showed that the abundance of $\sim 37 \%$ protein spots (40 out of 108 detected from 2-DE gel images) significantly varied with the sampling date. Significant decreases in the abundances of proteins involved in photosystem II (LHCP 4), electron transfer chain (Cyt c553), Calvin cycle (GAPDH), and chloroplast antioxidant system (2-Cys Prx) were observed as the bloom progressed, suggesting the efficiencies of those photosynthetic pathways declined during the bloom. In addition, the abundances of the above proteins showed significant positive correlations with the $\mathrm{F}_{\sqrt{ }} / \mathrm{F}_{\mathrm{m}}$ ratio and growth rate of $C$. marina and with DIN concentrations (except LHCP 4). Our findings suggested that declined expressions of those photosynthesis-related proteins presented some molecular foundation of the decreases in $\mathrm{F}_{\mathrm{v}} / \mathrm{F}_{\mathrm{m}}$ ratio and growth rate of $C$. marina during the bloom, and also provided insight into mechanistic links between the external/internal factors and physiological responses of $C$. marina that may ultimately dictate the ecology of the bloom.
\end{abstract}

Key words: Chattonella marina; $\mathrm{F} / \mathrm{F}_{\mathrm{n}}$ ratio; Growth rate; Harmful algal bloom; Proteomics Two-dimensional gel electrophoresis

\begin{abstract}
Abbreviations: 2-Cys Prx, 2-cysteine peroxiredoxin; 2-DE, two-dimensional gel electrophoresis; AtpB, ATP synthase CF 1 beta subunit; Cyt c553, Cytochrome c553; DIN, dissolved inorganic nitrogen $\left(\mathrm{NO}_{2}^{-}\right.$, $\mathrm{NO}_{3}{ }^{-}$, and $\mathrm{NH}_{4}^{+}$); DIP, dissolved inorganic phosphorus $\left(\mathrm{PO}_{4}^{3-}\right)$; GAPDH, glyceraldehyde-3-phosphate dehydrogenase; ISP: rieske (2Fe-2S) region protein; LHCP 4, chloroplast light harvesting protein isoform 4; OEE 1, oxygen evolving enhancer 1; RPL12, 50S ribosomal protein L12
\end{abstract}

\section{INTRODUCTION}

The harmful algal blooms (HABs) of species belonging to the genus Chattonella (Raphidophyceae) have been reported to cause significant economic and ecological damages in various regions of the world (Hallegraeff et al., 1998; Tiffany et al., 2001; Imai and Yamaguchi, 2012). Recent years, HABs of Chattonella spp. continually cause serious damages to aquaculture and fishery production in the coastal waters of western Japan (Yamatogi et al., 2006; Imai and Yamaguchi, 2012; Katano et al., 2012). Thus, numerous studies have been

Laboratory of Silviculture, Faculty of Agriculture, Kyushu University, Fukuoka 812-8581, Japan

${ }^{2}$ Saga Prefectural Ariake Fisheries Research and Development Center, Nagata 2753-2, Ashikari-cho, Ogi, Saga 849-0313, Japan

Laboratory of Biochemistry, Faculty of Agriculture, Kyushu University, Fukuoka 812-8581, Japan

${ }^{4}$ Laboratory of Bioresources Chemistry, Faculty of Agriculture, Kyushu University, Fukuoka 812-8581, Japan

${ }^{5}$ Graduate School of Frontier Science, Department of Natural Environmental Studies, The University of Tokyo, Kashiwanoha 5-1-5, Kashiwa-shi, Chiba 277-8564, Japan

${ }^{6}$ Seto Inland Sea Regional Research Center, Kagawa University, Saiwaichou 1-1, Takamatsu, Kagawa 760-8521, Japan

* Corresponding author: E-mail: xuchunqiu@agr.kyushu-u.ac.jp (X. Qiu) performed to reveal their life history, growth physiology, and bloom ecology (Imai and Yamaguchi, 2012). However, only a few studies have focused on physiological responses in Chattonella to various stresses via defined laboratory culture experiments (Warner and Madden, 2007; Portune et al., 2010; Qiu et al., 2013), while studies on mechanisms involved in cellular responses in field populations are completely lacking.

Proteomics, a large-scale study of the structure and function of proteins in complex biological samples, has been shown to have powerful potential with regard to revealing the physiological and metabolic characteristics of HAB species (Anderson et al., 2012; Poulson-Ellestad et al., 2014). Proteomics have been applied to the adaptive responses of marine dinoflagellates and diatoms under various environmental stresses (Wang et al., 2014; Yang et al., 2014; Muhseen et al., 2015). Although most proteomic studies on HAB species were conducted via laboratory culture experiments, obtained results have provided clues to elucidate the relationship between algae and environmental variables, and promoted our understanding of the biochemical processes that contribute to algal ecological success. Furthermore, a study combining field research and omics-related technologies has been considered as an essential and powerful way to ensure a comprehensive understanding of the factors that promote the HABs within specific environments (McLean, 
2013; Poulson-Ellestad et al., 2014; Wang et al., 2014).

Our previous proteomic analysis on batch cultured Chattonella marina var. antiqua (Hada) Demura \& Kawachi demonstrated that some phase-dependent expressed proteins have potential to serve as indicators for rapid assessment of cellular responses, and monitoring their abundance may provide useful information on the molecular mechanisms involved in the initiation and decline of algal blooms, by correlating those changes with physiological and ecological parameters (Qiu et al., 2013). In the present study, we investigated variations in protein profiles of field Chattonella cells at different stages of a HAB dominated by C. marina. Subsequently, we focused on photosynthesis related proteins and correlated their abundances with the measured physiological parameters $\left(\mathrm{F}_{\mathrm{v}} / \mathrm{F}_{\mathrm{m}}\right.$ ratio and growth rate of $C$. marina) and observed environmental variables (DIN, DIP, temperature, and salinity). This study aimed to gather information on the molecular mechanisms underlying the physiological responses in field C. marina population during HAB.

\section{MATERIAL AND METHODS}

\section{Field survey}

Seawater samples were collected at those stations located in the inner part of the Ariake Sea, Japan (Fig. 1). About $2 \mathrm{~L}$ seawater was collected from depths of 0,2 , and $5 \mathrm{~m}$ (depth permitting) using a Niskin water sampler (Model 1080, Rigo, Saitama, Japan), and were brought to the laboratory within $4 \mathrm{~h}$ from the first sampling time and used for subsequent experiments. The vertical profiles of water temperature and salinity were measured

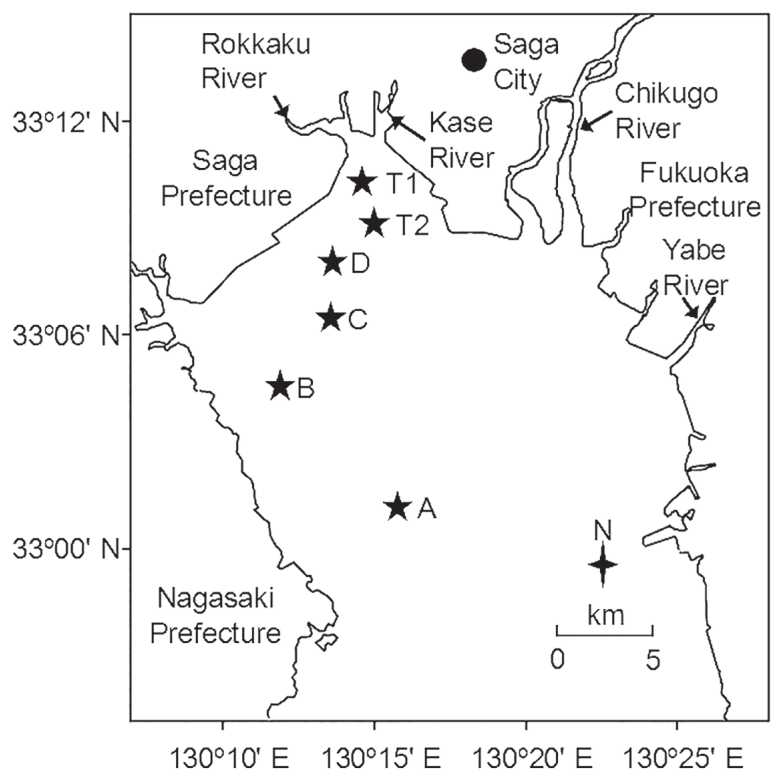

Fig. 1. Field sites for sampling from 5 to 18 September, 2012, in the inner part of Ariake Sea, Japan. Stars indicate the sampling stations: A $\left(33^{\circ} 01.165^{\prime} \mathrm{N}, 130^{\circ} 15.971^{\prime} \mathrm{E}\right), \mathrm{B}$ $\left(33^{\circ} 04.715^{\prime} \mathrm{N}, 130^{\circ} 10.885^{\prime} \mathrm{E}\right), \mathrm{C}\left(33^{\circ} 04.813^{\prime} \mathrm{N}\right.$ $\left.130^{\circ} 11.737^{\prime} \mathrm{E}\right), \mathrm{D}\left(33^{\circ} 07.157^{\prime} \mathrm{N}, 130^{\circ} 12.886^{\prime} \mathrm{E}\right), \mathrm{T} 1$ $\left(33^{\circ} 07.963^{\prime} \mathrm{N}, 130^{\circ} 13.436^{\prime} \mathrm{E}\right)$, T2 $\left(33^{\circ} 10.571^{\prime} \mathrm{N}\right.$, $\left.130^{\circ} 14.218^{\prime} \mathrm{E}\right)$. using a Compact-CTD recorder (Model ASTD687, ALEC Electronics Co., Ltd., Kobe, Japan). For phytoplankton counting, each bottle was gently turned upside down five times before subsamples were taken. Vegetative cells were counted under a microscope in triplicate $0.1 \mathrm{ml}$ subsamples. Subsequently, $50 \mathrm{ml}$ subsamples were gravityfiltered through glass microfiber filters (GF/C, Whatman International Ltd., Maidstone, UK), and then were passed through $0.22-\mu \mathrm{m}$ syringe filters. Those water samples were frozen at $-80^{\circ} \mathrm{C}$ for macronutrient analysis, The DIN and DIP concentrations were measured with an Autoanalyzer (TRACCS 2000; Bran + Luebbe, Hamburg, Germany).

\section{Determination of the Fv/Fm ratio and growth rate of $C$. marina}

The $\mathrm{F}_{\mathrm{v}} / \mathrm{F}_{\mathrm{m}}$ ratio was used as the photosynthetic activity indicator and determined on the sampling day. To avoid the potential impact of elevated irradiance on the $\mathrm{F}_{\mathrm{v}} / \mathrm{F}_{\mathrm{m}}$ ratio, seawater samples were kept under weak natural light $\left(<10 \mu \mathrm{mol} \mathrm{m}^{-2} \mathrm{~s}^{-1}\right)$ during transport. For $\mathrm{F}_{\mathrm{v}} / \mathrm{F}_{\mathrm{m}}$ ratio measurement, the bottle was gently turned upside down 5 times before subsamples $(1.5 \mathrm{ml})$ were taken. Subsequently, the subsamples were kept in darkness for at least $30 \mathrm{~min}$ and then assayed with a Xe-PAM fluorometer (H. Walz, Effeltrich, Germany), as described by Qiu et al. (Qiu et al., 2013). To determine the growth rate of C. marina, triplicate 25-ml subsamples were transferred into 70-ml sterile flasks (Nunc, Thermo Fisher Scientific Inc., Suwanee, GA, USA) on the sampling day (defined as day 1 ), and were grown in an incubator at $27.5^{\circ} \mathrm{C}$ under cool-white fluorescent illumination $\left(110 \pm 10 \mu \mathrm{mol} \mathrm{m}{ }^{-2}\right.$ $\mathrm{S}^{-1}$ ) at a 14:10 h light:dark cycle for 3 days. Phytoplankton cells were counted under a microscope in triplicate $0.1-$ $\mathrm{ml}$ subsamples on the day 3 , and the growth rate (GR, divisions $\mathrm{d}^{-1}$ ) of $C$. marina was determined as $\mathrm{GR}=$ $\mathrm{LN}\left(N_{3} / N_{1}\right) /[2 \mathrm{LN}(2)]$, where $N_{1}$ and $N_{3}$ are cell densities of $C$. marina on the days 1 and 3 (Guillard, 1973).

\section{Protein extraction and 2-DE}

To collect sufficient cells for 2-DE, about $500 \mathrm{ml}$ seawater samples were transferred into 1-l clean plastic jars, and those jars were let stand for 30-60 min until the $C$. marina had concentrated in the surface of water. Subsequently, $120 \mathrm{ml}$ supernatant suspensions were transferred into four 50-ml centrifuge tube and $C$. marina cells were obtained by centrifugation at $670 \times \mathrm{g}$ at $25^{\circ} \mathrm{C}$ for $5 \mathrm{~min}$. After triplicate re-suspensions with sterile seawater and centrifugations, Chattonella cell pellets were stored at $-80^{\circ} \mathrm{C}$ until protein extraction.

With an Analog sonifier (Model 250, Branson Ultrasonics Co., Danbury, CT, USA) cell pellets were lysed in $3 \mathrm{ml}$ of extraction buffer (7 M urea, $2 \mathrm{M}$ thiourea, $4 \%$ w/v CHAPS, $5 \mathrm{mM}$ magnesium acetate) on ice, and the resulting homogenate was centrifuged at $10,000 \times g$ at $4^{\circ} \mathrm{C}$ for $10 \mathrm{~min}$. Subsequently, the supernatant was transferred into a new centrifuge tube containing $12 \mathrm{ml}$ of cold acetone $\left(-20^{\circ} \mathrm{C}\right)$, and the mixture was maintained at $-20^{\circ} \mathrm{C}$ for at least $2 \mathrm{~h}$, after which the mixture was centrifuged at $10,000 \times g$ at $4^{\circ} \mathrm{C}$ for $10 \mathrm{~min}$. Repeated re- 
suspensions with cold acetone and centrifugations were conducted for 3 times to remove substances that might interfere with the first dimension (isoelectric focusing) of the electrophoresis. The resulting protein pellet was dried at room temperature and dissolved in $0.5 \mathrm{ml}$ of urea buffer (7 M urea, $2 \mathrm{M}$ thiourea, 4\% w/v CHAPS, 2\% w/v DTT, trace amount of bromophenol blue) by vortex mixing and sonication.

Protein concentration of each sample was measured with a BCA protein assay kit (Thermo Scientific, Pierce, IL, USA). Exactly $0.5 \mathrm{mg}$ of protein $(350 \mu \mathrm{l})$ with $1.75 \mu \mathrm{l}$ of IPG (immobilized $\mathrm{pH}$ gradient) buffer ( $\mathrm{pH} 4-7$, GE Healthcare, Uppsala, Sweden) was loaded onto each IPG strip ( $\mathrm{pH} 4-7,18 \mathrm{~cm}$, GE Healthcare). After rehydration for $10 \mathrm{~h}$ at $20^{\circ} \mathrm{C}$, isoelectric focusing (IEF) was performed with an Ettan IPGphor 3 system (GE Healthcare) using the following program at $20^{\circ} \mathrm{C}: 500 \mathrm{~V}$ for $4 \mathrm{~h}$, a linear gradient to $1,000 \mathrm{~V}$ over $1 \mathrm{~h}$, a linear gradient to $8,000 \mathrm{~V}$ over $2 \mathrm{~h}$, and $8,000 \mathrm{~V}$ for $7 \mathrm{~h}$. The focused IPG strips were equilibrated in equilibration buffer (6 M urea, 30\% w/v glycerol, $2 \% \mathrm{w} / \mathrm{v}$ SDS, $50 \mathrm{mM}$ Tris- $\mathrm{HCl}$, and a trace of bromophenol blue, $\mathrm{pH}$ 8.8) supplemented with $130 \mathrm{mM}$ DTT for $10 \mathrm{~min}$ and subsequently equilibrated with the same buffer containing $135 \mathrm{mM}$ iodoacetamide (instead of DTT) for $10 \mathrm{~min}$. For the second dimension electrophoresis, the equilibrated strips were loaded onto $12 \%$ SDS-polyacrylamide gels $(20 \times 20 \mathrm{~cm})$. The gels were run in a Protean II xi 2-D system (Bio-Rad, Hercules, CA, USA) at $25 \mathrm{~mA}$ for $1.5 \mathrm{~h}$ and $35 \mathrm{~mA}$ per gel until the front dye reached the bottom of the gel at $10^{\circ} \mathrm{C}$. To consider technical variation, protein extract from each sample was analyzed 3 times. This resulted in a total of 33 gels used for subsequent correlation analysis.

\section{Image capture, abundance analysis, and protein identification}

The 2-DE gels were fixed in $10 \%(\mathrm{w} / \mathrm{w})$ acetic acid and 40\% (w/w) ethanol for $6 \mathrm{~h}$ and stained with Flamingo gel stain solution (Bio-Rad) for $3 \mathrm{~h}$. The stained gels were scanned at a resolution of 100 dots $\mathrm{cm}^{-1}$ by an FX molecular imager (Bio-Rad). The gel images were analyzed by Proteomweaver 2-D analysis software version 4.0 (Bio-Rad). The relative protein abundance in each spot was analyzed with automated routines from the software combined with manual editing to remove artifacts.

For protein identification, protein spots in 2-DE gels were electrotransferred onto PVDF membranes (BioRad) with a Semi-dry transblot apparatus (ATTO, Tokyo, Japan). The PVDF membrane-bound proteins were visualized by staining with $0.1 \% \mathrm{w} / \mathrm{v}$ amido black in $45 \% \mathrm{v} / \mathrm{v}$ methanol for $10 \mathrm{~min}$ and destained in distilled water. Selected protein spots were excised and analysis of $N$ terminal amino acid sequences was determined by a PSQ-1 protein sequencer (Shimadzu, Kyoto, Japan). Obtained amino acid sequences were firstly searched against NCBI-BLAST using protein-protein BLAST algorithm with a non-redundant (nr) protein database (http://www.ncbi.nlm.nih.gov/protein/). Those sequences that failed to find a match were then searched against the available sequences of Chattonellaceae (taxid: 658124) and Heterokonts (taxid: 33634) to find homologous proteins with default parameters.

\section{Statistical analysis}

Spearman's rank correlation coefficient (rs) was used to examine the correlation of abundance of each protein spot detected by $2-\mathrm{DE}$ with sampling date, $\mathrm{F}_{\mathrm{v}} / \mathrm{F}_{\mathrm{m}}$ ratio and growth rate of $C$. marina, and observed environmental variables (DIN, DIP, temperature, and salinity). Considering Chattonella cells have diel vertical migration behavior (Watanabe et al., 1991) and can migrate to a depth of about $5 \mathrm{~m}$ for taking up nutrient in the Ariake Sea (Katano et al., 2012), the average values of environmental variables (Table 1 ) of seawater samples collected from depths of 0,2 , and $5 \mathrm{~m}$ (depth permitting) in the same station were used for the above correlation analy-

Table 1. Cell abundance, $\mathrm{F}_{\mathrm{v}} / \mathrm{F}_{\mathrm{m}}$ ratio, and growth rate of Chattonella marina, as well as environmental variables in seawater samples used for proteomic analysis

\begin{tabular}{|c|c|c|c|c|c|c|c|c|}
\hline \multirow{2}{*}{$\begin{array}{l}\text { Sampling } \\
\text { date }\end{array}$} & \multirow{2}{*}{ Site } & \multirow{2}{*}{$\begin{array}{l}\text { Abundance } \\
\left(\text { cells } \cdot \mathrm{mL}^{-1}\right)\end{array}$} & \multirow{2}{*}{$\begin{array}{l}\mathrm{F}_{\mathrm{v}} / \mathrm{F}_{\mathrm{m}} \\
\text { ratio }\end{array}$} & \multirow{2}{*}{$\begin{array}{l}\text { Growth rate } \\
\left(\text { division } \cdot \mathrm{d}^{-1} \text { ) }\right.\end{array}$} & \multicolumn{4}{|c|}{ Environmental variables ${ }^{\mathrm{a}}$} \\
\hline & & & & & $\mathrm{DIN}(\mu \mathrm{M})$ & $\mathrm{DIP}(\mu \mathrm{M})$ & Temperature $\left({ }^{\circ} \mathrm{C}\right)$ & Salinity \\
\hline \multirow[t]{2}{*}{ 5-Sep } & Station A & 1030 & 0.710 & 0.380 & 1.38 & 0.62 & 27.55 & 27.77 \\
\hline & Station B & 2350 & 0.716 & 0.221 & 3.12 & 1.19 & 27.66 & 27.37 \\
\hline \multirow[t]{2}{*}{ 7-Sep } & Station C & 9444 & 0.711 & 0.278 & 1.39 & 0.76 & 29.43 & 24.45 \\
\hline & Station D & 950 & 0.712 & 0.788 & 5.48 & 1.52 & 29.28 & 23.97 \\
\hline \multirow[t]{2}{*}{ 10-Sep } & Station C & 2340 & 0.665 & 0.498 & 1.37 & 0.65 & 28.17 & 22.75 \\
\hline & Station B & 6100 & 0.661 & 0.276 & 0.48 & 0.77 & 28.05 & 23.12 \\
\hline \multirow[t]{3}{*}{ 12-Sep } & Station T1 & 8667 & 0.690 & 0.097 & 0.79 & 0.72 & 27.37 & 25.01 \\
\hline & Station D & 3217 & 0.651 & 0.196 & 0.43 & 1.34 & 27.14 & 24.61 \\
\hline & Station T2 & 6817 & 0.672 & 0.205 & 0.48 & 1.98 & 27.38 & 26.35 \\
\hline \multirow[t]{2}{*}{ 14-Sep } & Station C & 5948 & 0.648 & -0.109 & 0.45 & 1.90 & 28.15 & 26.60 \\
\hline & Station B & 4383 & 0.637 & -0.027 & 0.39 & 1.35 & 28.20 & 26.70 \\
\hline
\end{tabular}

${ }^{a}$ The average values of seawater samples collected from the depth of 0,2 , and $5 \mathrm{~m}$ (depth permitting) in the same station. 
sis. All statistical analyses were performed using the Statistical Package for the Social Sciences software (SPSS 11.0; SPSS, Inc., Chicago, IL, USA).

\section{RESULTS}

On the basis of the dominance (became monospecific or almost dominated the phytoplankton community) and
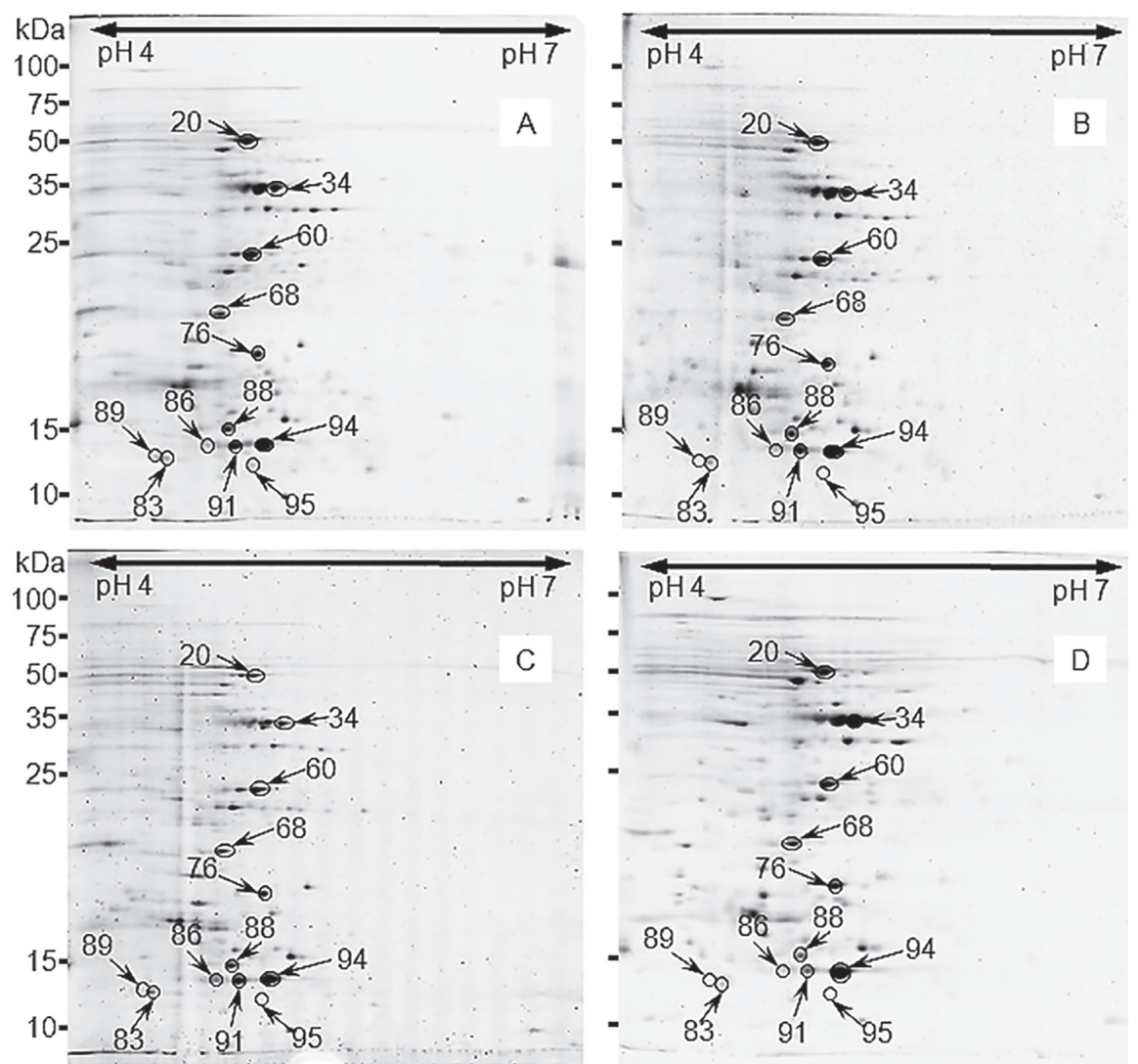

Fig. 2. Representative 2-DE maps of field Chattonella marina cells in seawater samples collected in the station B on 5 (A), 7 (B), 14 (C) September, 2012, as well as that of $C$. marina var. antiqua at early stationary phase (NIES-1 strain, 16,000 cells $\mathrm{ml}^{-1}$ ) of a sterile batch culture (D). The numeric labeling of the spots in corresponds to the numbers assigned in Table 2.

Table 2. Proteins identified by $N$-terminal amino acid sequencing

\begin{tabular}{|c|c|c|c|c|c|c|c|}
\hline \multirow{2}{*}{$\begin{array}{l}\text { Spot } \\
\text { No. }{ }^{a}\end{array}$} & \multirow{2}{*}{$\begin{array}{l}N \text {-terminal amino } \\
\text { acid sequencing }\end{array}$} & \multirow{2}{*}{$\begin{array}{l}\text { Matched proteins [marched } \\
\text { species] }^{\mathrm{b}}\end{array}$} & \multirow{2}{*}{$\begin{array}{l}\text { Accession } \\
\text { No. }\end{array}$} & \multirow{2}{*}{ Identity } & \multirow{2}{*}{ E-value } & \multicolumn{2}{|c|}{$\mathrm{MW}(\mathrm{kDa}) / p \mathrm{I}$} \\
\hline & & & & & & Observed & Calculated \\
\hline 20 & METTNESLGYTDQIIGPVLD & AtpB [H. akashiwo] & YP_001936399.1 & $17 / 20(85 \%)$ & $2.0 \mathrm{E}-08$ & $51.0 / 5.30$ & $51.0 / 5.07$ \\
\hline 34 & EGDVIATGINGFGRIG & GAPDH [D. dichotoma $]$ & ABU54834.1 & $11 / 13(85 \%)$ & $6.0 \mathrm{E}-03$ & $36.0 / 5.65$ & $36.4 / 5.42$ \\
\hline 60 & ITKEELRSLDYLQVKGVGLA & OEE1 [H. akashiwo] & AAN11311.1 & $16 / 20(80 \%)$ & $6.0 \mathrm{E}-06$ & $29.5 / 5.40$ & $31.9 / 5.52$ \\
\hline 68 & SIRVGQKAPDFTATAVFDQE & 2-Cys Prx [H. akashiwo] & YP_001936352.1 & $13 / 19(68 \%)$ & $8.0 \mathrm{E}-03$ & $23.0 / 4.90$ & $22.0 / 4.89$ \\
\hline 76 & KLGSSAQGLIGSDLXXPXF & LHCP $4[N$. gaditana $]$ & EWM23957.1 & $14 / 19(74 \%)$ & $1.0 \mathrm{E}-04$ & $21.0 / 5.50$ & $23.4 / 5.44$ \\
\hline 83 & ADIENGEDIFTANAS & Cyt c553 [H. akashiwo] & YP_001936409.1 & $12 / 13(92 \%)$ & $7.6 \mathrm{E}-07$ & $12.0 / 4.80$ & $12.1 / 5.02$ \\
\hline 86 & MRLTQGAFLXLP & RUBISCO SSU [C. marina] & BAS54019.1 & $10 / 12(83 \%)$ & $2.2 \mathrm{E}-02$ & $16.5 / 4.90$ & $16.1 / 5.01$ \\
\hline 88 & AGVKAKDEWVXXLL & $\operatorname{ISP}[N$. gaditana $]$ & EWM24009.1 & $10 / 12(83 \%)$ & $4.0 \mathrm{E}-03$ & $18.0 / 5.00$ & $20.6 / 5.66$ \\
\hline 89 & SKVENIVDELKTLTL & RPL12 [H. akashiwo] & YP_001936329.1 & $12 / 15(80 \%)$ & $1.0 \mathrm{E}-05$ & $13.0 / 4.60$ & $13.5 / 4.55$ \\
\hline 91 & MRLTQGAFSYLXDXH & RUBISCO SSU [C. marina] & BAS54019.1 & $12 / 13(92 \%)$ & $1.0 \mathrm{E}-05$ & $16.5 / 5.30$ & $16.1 / 5.01$ \\
\hline 94 & MRLTQGAFSYLPDLTDAQII & RUBISCO SSU [C. marina] & BAS54019.1 & $20 / 20(100 \%)$ & $2.0 \mathrm{E}-14$ & $16.5 / 5.50$ & $16.1 / 5.01$ \\
\hline 95 & MRLTQGAFSYLPDLXDAQXI & RUBISCO SSU [C. marina $]$ & BAS54019.1 & $18 / 20(90 \%)$ & $6.0 \mathrm{E}-12$ & $14.0 / 5.40$ & $16.1 / 5.01$ \\
\hline
\end{tabular}

a The protein spot numbers are given in Fig. 2.

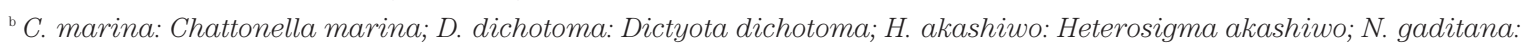

Nannochloropsis gaditana 
abundance (peak densities of each sampling day), $C$. marina cells in a total of 11 samples ( 2 or 3 samples per sampling date) were selected for proteomic analysis, as shown in Table 1. As the bloom progressed, both $\mathrm{F}_{\mathrm{v}} / \mathrm{F}_{\mathrm{m}}$ ratio $(0.64-0.72)$ and growth rate $\left(-0.1-0.29\right.$ div. $\left.\mathrm{d}^{-1}\right)$ of C. marina cells showed a tendency to decrease throughout the sampling period. Relative small variations in the average temperature $\left(27.1-29.4^{\circ} \mathrm{C}\right)$, salinity (22.8-27.8), and DIP c oncentration $(0.62-1.98 \mu \mathrm{M})$ were observed in the above sample. Relative low DIN $(0.39-5.48 \mu \mathrm{M})$ were recorded during the bloom, especially after 10 September, $2012(<0.8 \mu \mathrm{M})$.
Proteomics of vegetative cells of $C$. marina in seawater samples were performed to track variations in their protein expression patterns throughout the HAB (Table 1). The 2-DE protein profiles of field C. marina cells shared a majority of common protein spots (Fig. 2A-C), which were also found to be similar to those of $C$. marina var. antiqua cultured in laboratory (Fig. 2D). Among 108 protein spots detected from the Flamingo-stained 2-DE gels, 77 spots matched in at least $85 \%$ ( $\geq 28$ gels) of all the 3 gels, which were used for further correlation analysis. Based on the Spearman's rank correlation between abundance of each protein spot and sampling date,

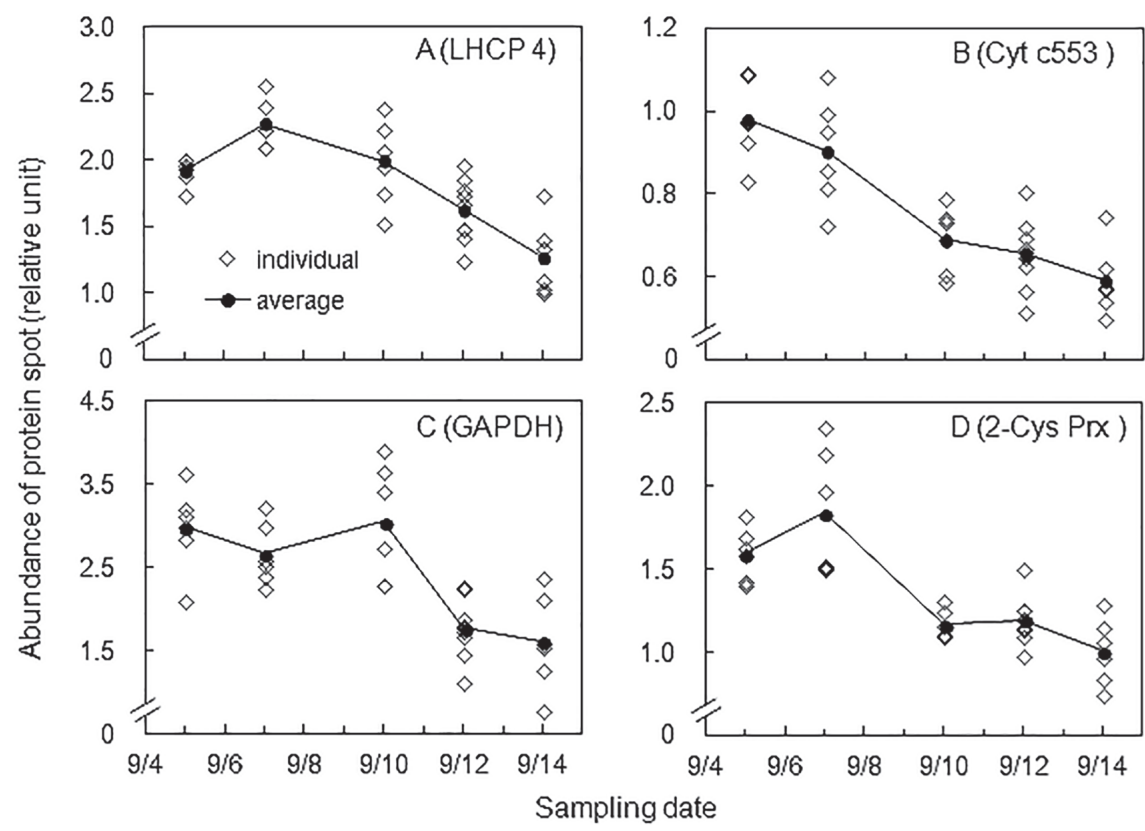

Fig. 3. Temporal variations in the expression levels of LHCP 4 (A), Cyt c553 (B), GAPDH (C), and 2-Cys Prx (D). Diamonds indicate relative abundance of protein spot in individual 2-DE gels and lines indicate the average values of all gels on the same sampling day. Note the different scales in vertical axis.

Table 3. Correlations of abundance of identified protein spots with physiological parameters and with environmental variables

\begin{tabular}{|c|c|c|c|c|c|c|c|}
\hline \multirow{3}{*}{ Proteins (spot number) ${ }^{a}$} & \multicolumn{7}{|c|}{ Spearman's coefficient ${ }^{\mathrm{b}}$} \\
\hline & \multicolumn{2}{|c|}{ Physiological parameters } & \multicolumn{5}{|c|}{ Environmental variables } \\
\hline & $\mathrm{F}_{\mathrm{v}} / \mathrm{F}_{\mathrm{m}}$ ratio & Growth rate & Sampling date & DIN & DIP & Temperature & Salinity \\
\hline AtpB (20) & 0.102 & 0.214 & -0.113 & -0.154 & -0.115 & -0.059 & -0.336 \\
\hline GAPDH (34) & $0.523^{* *}$ & $0.620^{* *}$ & $-0.712^{* *}$ & $0.457^{* * *}$ & $-0.487 * *$ & 0.235 & -0.183 \\
\hline OEE1 (60) & 0.101 & 0.313 & -0.161 & -0.078 & -0.091 & 0.116 & -0.239 \\
\hline 2-Cys Prx (68) & $0.771 * *$ & $0.494 * *$ & $-0.762 * *$ & $0.702 * *$ & -0.323 & 0.174 & 0.149 \\
\hline LHCP 4 (76) & $0.602 * *$ & $0.829 * *$ & $-0.696 * *$ & 0.176 & -0.245 & $0.371^{*}$ & $-0.346^{*}$ \\
\hline Cyt c553 (83) & $0.780 * *$ & $0.574 * *$ & $-0.812 * *$ & $0.628 * *$ & -0.197 & 0.201 & 0.257 \\
\hline ISP (88) & 0.043 & 0.107 & -0.206 & 0.056 & 0.026 & -0.046 & -0.148 \\
\hline RPL12 (89) & 0.284 & -0.305 & -0.094 & 0.192 & 0.112 & 0.006 & $0.509 * *$ \\
\hline RUBISCO SSU (86) & 0.043 & 0.158 & -0.206 & 0.056 & 0.026 & -0.148 & -0.016 \\
\hline RUBISCO SSU (91) & -0.183 & -0.284 & 0.208 & -0.090 & 0.019 & -0.307 & -0.115 \\
\hline RUBISCO SSU (94) & 0.018 & 0.189 & -0.057 & -0.160 & -0.103 & -0.142 & $-0.377^{*}$ \\
\hline
\end{tabular}

a The protein spot's information is given in Fig. 2 and Table 2, respectively.

${ }^{\mathrm{b}}$ Correlations were analyzed by Spearman's rank correlation $(N=33 ; *, P<0.05$; **, $P<0.01)$ 
expression of 40 protein spots significantly decrease (33 spots; $P<0.05)$ or increase $(7$ spots; $P<0.05$ ) as the bloom progressed.

The $N$-terminal amino acid sequences of 15 protein spots were sequenced successfully, out of which 12 spots were identified as isoforms or enzymes involved in photosynthesis (Table 2). These identified proteins are involved in the PS II (spot 60 and 76), electron transfer (spot 83 and 88), ATP synthesis (spot 20), Calvin cycle (spots 34, 86, 91, 94, and 95), chloroplastic antioxidant system (spot 68), and chloroplastic protein synthesis (spot 89). Correlations between abundance of identified protein spots and physiological parameters and environmental variables are listed in the Table 3. Significant decreases in the expression of LHCP 4 (spot 76), Cyt c553 (spot 83), GAPDH (spot 34), and 2-Cys Prx (spot 68) were observed as the bloom progressed (Fig. 3A-D), and their abundances were also parallel significantly correlated with the $\mathrm{F}_{\mathrm{v}} / \mathrm{F}_{\mathrm{m}}$ ratio and growth rate of $C$. marina (Spearman's rank correlation, $P<0.01$, Table 3 ).

\section{DISCUSSION}

This study represents the first attempt that using proteomics to investigate time series variations in protein expression profiles of field $C$. marina populations throughout a HAB when they became dominant. The dynamics of Chattonella cells during the HAB has been described in detail in our previous report (Qiu et al., 2016), and exhaustion of DIN concentration was likely responsible for controlling the photosynthetic activity and growth of algal cells. Assuming that the minimum cell quotas of nitrogen and phosphorus for $C$. marina var. antiqua are 7.7 and 0.60 pmol cell ${ }^{-1}$ (Nakamura, 1985), increase of 1000 cells in a milliliter water corresponds to consumptions of 7.7 and $0.6 \mu \mathrm{M}$, respectively. From this aspect, the DIN in samples used for proteomic analysis was likely a limited factor for the growth of $C$. marina cells, and become insufficient at the terminal stage of the HAB (Table 1). Indeed, the growth rate of $C$. marina decreased to $<0$ divisions $\mathrm{d}^{-1}$ on 14 September, associated with the declined $\mathrm{F}_{\mathrm{v}} / \mathrm{F}_{\mathrm{m}}$ ratios.

Proteomic study found that $C$. marina showed constancy of protein profiles at the different stages of the HAB (Fig. 2), suggested that the cells may maintain most of their protein functionality, even at the end of the bloom. Invariance of protein profiles was also observed in the C. marina var. antiqua (Qiu et al., 2013) and the dinoflagellate Prorocentrum triestinum (Chan et al., 2004) at different growth phases of batch culture. Given that equal amounts of proteins were loaded onto each gel, however, about 37\% protein spots showed abundances significantly varied with sampling date, which are thought to play critical roles in mediating cellular responses and growth of C. marina during the HAB. Identification of proteins spots (Fig. 2 and Table 2 ) and subsequent correlation analysis (Table 3 ) suggested that variations in the expression levels of LHCP 4 (spot 76), Cyt c553 (spot 83), GAPDH (spot 34), and 2-Cys Prx (spot 68) present some molecular foundation of the physiological responses in $C$. marina cells during the bloom.

Pronounced decrease in abundance LHCP 4 (spot 76, Fig. 3A) may impair light absorption ability and thereby caused the decline of $\mathrm{F}_{v} / \mathrm{F}_{\mathrm{m}}$ ratio of $C$. marina (Table 1 ). The LHCP 4 is an isoform of light harvesting complex, which binds antenna chlorophyll and carotenoid pigments that augment light-capturing capacity of photosynthetic reaction centers of PS II (Green and Durnford, 1996; Durnford et al., 1999). Since light absorption during photosynthesis is directly related to algal cell productivity, declined expression of LHCP 4 may also reduce the growth rate of $C$. marina. Those inferences were supported by correlation analysis, which showed that the abundance of LHCP 4 has significant positive correlations with both $\mathrm{F}_{\mathrm{v}} / \mathrm{F}_{\mathrm{m}}$ ratio and growth rate of $C$. marina (Table 3).

Constantly decrease in the abundance of Cyt c553 (spot 83) suggested the electron transport ability of $C$. marina cells declined as the bloom progressed. Similar temporal decline in expression of Cyt c553 was also observed during the batch cultures of $C$. marina var. antiqua (Qiu et al., 2013), suggesting cellular senescence is one of the factors leading to declined expression of this protein. Since Cyt c553 is a mobile cytochrome that functions in the transfer of reducing equivalents from the cytochrome $b_{6} f$ complex to PSI or ferredoxin (Merchant and Dreyfuss, 1998; Behrenfeld et al., 2006), declined expression of this protein may result in lower amount of electron available for the production of ATP and NADPH, which are used to promote the subsequent chemical processes of light-independent reactions.

As a key enzymes of Calvin cycle, GAPDH (spot 34) catalyzes the reduction of 1,3-bisphosphoglyceric acid by NADPH to produce glyceraldehyde-3-phosphate (GAP) and inorganic phosphate. Because GAP is also an intermediate in the pathways of glycolysis and gluconeogenesis in plant and algae, GAPDH plays strategic roles in those cell metabolisms (Henze et al., 1995; Liaud et al., 2000; Trost et al., 2006; Mekhalfi et al., 2014). The notably declined expression of GAPDH in C. marina a few days prior to bloom termination (Fig. 3C) may impair those metabolic pathways and result in lower production of organic compounds. However, our previous study showed that GAPDH displayed a phase-dependent increased abundance during batch culture of $C$. marina var. antiqua (Qiu et al., 2013). Considering the difference in the nitrogen concentrations between the previous batch cultures (about $199 \mu \mathrm{M}$ at late stationary phase) and the present field observation $(<1 \mu \mathrm{M}$ at the end of the bloom), we inferred that nitrogen limitation was one of the important factors that induced the decrease expression in GAPDH during the bloom. Consistent with this, significant positive correlations between abundance of GAPDH and DIN concentration was observed during the bloom (Table 3). Nitrogen deprivation induced declined expression of GAPDH at transcript and/or protein levels has also been demonstrated in several studies on diatoms (Hockin et al., 2012; Yang et al., 2014) and green algae (Juergens et al., 2015). In addition, carbon and nitrogen metabolism in plant and 
algal cells are closely linked (Huppe and Turpin, 1994), and reduced nitrate assimilation causes metabolic imbalance leading to increased oxidative stress (Logan et al., 1999; Blaby et al., 2013).

Notable decrease in abundance of the antioxidant enzyme 2-Cys Prx (spot 68) was observed as the bloom progressed (Fig. 3D). Similarly, significant decrease in 2-Cys Prx prior to rapid cell death were also found in batch cultured C. marina var. antiqua (Qiu et al., 2013). It seems that cellular senescence is one of the critical factors leading to declined expression of this protein in Chattonella cells, as reported in various high plants (Baier and Dietz, 1996; Baier and Dietz, 1999; Horling et al., 2001). In various transgenic high plant or cyanobacteria, deficiency in 2-Cys Prx resulted in lower growth, inhibited photosynthesis, and higher stress sensitivity (Dietz, 2011). Those findings supported our results that abundance of 2-Cys Prx had significant positive correlations with both the growth rate and $\mathrm{F}_{\mathrm{v}} / \mathrm{F}_{\mathrm{m}}$ ratio of $C$. marina during the HAB (Table 3). Chattonella is known to produce high levels of reactive oxygen species associated with photosynthesis and cell growth (Kim et al., 2004; Kim et al., 2006; Portune et al., 2010), and therefore large amount of antioxidant enzymes is necessary to protect themselves during active growth. As the bloom progressed, lower amount of 2-Cys Prx may become insufficient and result in peroxides accumulation within cells, which can impair the photosynthesis by damaging chloroplast structures (Baier and Dietz, 1999), and finally may induce the rapid termination of the bloom by triggering peroxide signaling events leading to cellular apoptosis (Wood et al., 2003).

In summary, the present proteomic study using field C. marina population demonstrates variations in abundances of some photosynthesis-related proteins can provided some insights into mechanistic links between external and/or internal factors (e.g., nitrogen limit and/or cellular senescence) and physiological responses (declined $\mathrm{F}_{\mathrm{v}} / \mathrm{F}_{\mathrm{m}}$ ratio and growth rate) that may ultimately dictate the ecology of the bloom. Besides those indentified photosynthetic proteins, proteomic analysis of $C$. marina also detected many other differentially expressed proteins as the bloom progressed. Further study is necessary to investigate the synthesis and functions of those differentially expressed proteins of $C$. marina during a field $\mathrm{HAB}$, which can ensure a more comprehensive understanding of their ecophysiology and bloom dynamics within specific environment conditions.

\section{AUTHOR CONTRIBUTIONS}

X. Qiu designed the study, performed the proteomic analysis and amino acid sequencing, analyzed the data and wrote the paper. K. Mukai performed the amino acid sequencing. Y. Shimasaki designed the study, performed the field sampling and amino acid sequencing, wrote the paper. M. Tsuyama analyzed the data. T. Matsubara performed the field sampling. T. Nakashima performed the amino acid sequencing. H. Ichinose and Y. Nakajima performed the proteomic analysis. T. Honjo supervised the work. Y. Oshima wrote the paper, supervised the work. All authors assisted in editing of the manuscript and approved the final version.

\section{ACKNOWLEDGEMENTS}

This study was partially supported by a grant from the Ministry of Education, Culture, Sports, Science and Technology of Japan (23780197) and a FY2012 Japan Society for the Promotion of Science Postdoctoral Fellowship for Foreign Researchers (P12405).

\section{REFERENCES}

Amirat, L.; M. Anton; D. Tainturier; G. R. Chatagnon; I. Battut and Anderson, D. M., A. D. Cembella and G. M. Hallegraeff 2012 Progress in understanding harmful algal blooms: paradigm shifts and new technologies for research, monitoring, and management. Ann. Rev. Mar. Sci., 4: 143-176

Baier, M. and K.-J. Dietz 1996 Primary structure and expression of plant homologues of animal and fungal thioredoxin-dependent peroxide reductases and bacterial alkyl hydroperoxide reductases. Plant Mol. Biol., 31: 553-564

Baier, M. and K.-J. Dietz 1999 Protective function of chloroplast 2-cysteine peroxiredoxin in photosynthesis. Evidence from transgenic Arabidopsis. Plant Physiol., 119: 1407-1414

Behrenfeld, M. J., K. Worthington, R. M. Sherrell, F. P. Chavez, P. Strutton, M. McPhaden and D. M. Shea 2006 Controls on tropical Pacific Ocean productivity revealed through nutrient stress diagnostics. Nature, 442: 1025-1028

Blaby, I. K., A. G. Glaesener, T. Mettler, S. T. Fitz-Gibbon, S. D. Gallaher, B. Liu, N. R. Boyle, J. Kropat, M. Stitt and S. Johnson 2013 Systems-level analysis of nitrogen starvation-induced modifications of carbon metabolism in a Chlamydomonas reinhardtii starchless mutant. Plant Cell, 25: 4305-4323

Chan, L. L., I. J. Hodgkiss, J. M. F. Wan, J. H. K. Lum, A. S. C. Mak, W. H. Sit and S. C. L. Lo 2004 Proteomic study of a model causative agent of harmful algal blooms, Prorocentrum triestinum II: the use of differentially expressed protein profiles under different growth phases and growth conditions for bloom prediction. Proteomics, 4: 3214-3226

Dietz, K.-J. 2011 Peroxiredoxins in plants and cyanobacteria Antioxid. Redox Signal., 15: 1129-1159

Durnford, D., J. Deane, S. Tan, G. McFadden, E. Gantt and B. Green 1999 A phylogenetic assessment of the eukaryotic light-harvesting antenna proteins, with implications for plastid evolution. J. Mol. Evol., 48: 59-68

Green, B. and D. Durnford 1996 The chlorophyll-carotenoid proteins of oxygenic photosynthesis. Annu. Rev. Plant Biol., 47: $685-714$

Guillard, R. 1973 Division rates. In Handbook of phycological methods (Stein, J.R., editor), Cambridge University Press, Cambridge, 289-312

Hallegraeff, G., B. Munday, D. Baden and P. Whitney 1998 Chattonella marina raphidophyte bloom associated with mortality of cultured bluefin tuna (Thunnus maccoyii) in South Australia. In Harmful Microalgae, 1-5

Henze, K., A. Badr, M. Wettern, R. Cerff and W. Martin 1995 A nuclear gene of eubacterial origin in Euglena gracilis reflects cryptic endosymbioses during protist evolution. Proc. Natl. Acad. Sci. U.S.A., 92: 9122-9126

Hockin, N. L., T. Mock, F. Mulholland, S. Kopriva and G. Malin 2012 The response of diatom central carbon metabolism to nitrogen starvation is different from that of green algae and higher plants. Plant Physiol., 158: 299-312

Horling, F., M. Baier and K.-J. Dietz 2001 Redox-regulation of the expression of the peroxide-detoxifying chloroplast 2-cys peroxiredoxin in the liverwort Riccia fluitans. Planta, 214 304-313 
Huppe, H. and D. Turpin 1994 Integration of carbon and nitrogen metabolism in plant and algal cells. Annu. Rev. Plant Biol., 45: $577-607$

Imai, I. and M. Yamaguchi 2012 Life cycle, physiology, ecology and red tide occurrences of the fish-killing raphidophyte Chattonella. Harmful Algae, 14: 46-70

Juergens, M. T., R. R. Deshpande, B. F. Lucker, J.-J. Park, H. Wang, M. Gargouri, F. O. Holguin, B. Disbrow, T. Schaub and J. N. Skepper 2015 The regulation of photosynthetic structure and function during nitrogen deprivation in Chlamydomonas reinhardtii. Plant Physiol., 167: 558-573

Katano, T., K. Yoshino, T. Matsubara and Y. Hayami 2012 Wax and wane of Chattonella (Raphidophyceae) bloom with special reference to competition between Skeletonema (Bacillariophyceae) in the Ariake Sea, Japan. J. Oceanogr., 68: $497-507$

Kim, D., M. Watanabe, Y. Nakayasu and K. Kohata 2004 Production of superoxide anion and hydrogen peroxide associated with cell growth of Chattonella antiqua. Aquat. Microb. Ecol., 35: 57-64

Kim, D., K. Yamaguchi and T. Oda 2006 Nitric oxide synthaselike enzyme mediated nitric oxide generation by harmful red tide phytoplankton, Chattonella marina. J. Plankton Res., 28: $613-620$

Liaud, M.-F., C. Lichtl, K. Apt, W. Martin and R. Cerff 2000 Compartment-specific isoforms of TPI and GAPDH are imported into diatom mitochondria as a fusion protein: evidence in favor of a mitochondrial origin of the eukaryotic glycolytic pathway. Mol. Biol. Evol., 17: 213-223

Logan, B. A., B. Demmig-Adams, T. N. Rosenstiel and W. W. Adams Iii 1999 Effect of nitrogen limitation on foliar antioxidants in relationship to other metabolic characteristics. Planta, 209: $213-220$

McLean, T. I. 2013 "Eco-omics": a review of the application of genomics, transcriptomics, and proteomics for the study of the ecology of harmful algae. Microb. Ecol., 65: 901-915

Mekhalfi, M., C. Puppo, L. Avilan, R. Lebrun, P. Mansuelle, S. C. Maberly and B. Gontero 2014 Glyceraldehyde-3-phosphate dehydrogenase is regulated by ferredoxin-NADP reductase in the diatom Asterionella formosa. New Phytol., 203: 414-423

Merchant, S. and B.W. Dreyfuss 1998 Posttranslational assembly of photosynthetic metalloproteins. Annu. Rev. Plant Biol., 49: $25-51$

Muhseen, Z. T., Q. Xiong, Z. Chen and F. Ge 2015 Proteomics studies on stress responses in diatoms. Proteomics, 15: 3943-3953

Nakamura, Y. 1985 Kinetics of nitrogen- or phosphorus-limited growth and effects of growth conditions on nutrient uptake in Chattonella antiqua. J. Oceanogr., 41: 381-387

Portune, K. J., S. Craig Cary and M. E. Warner 2010 Antioxidant enzyme response and reactive oxygen species production in marine raphidophytes. J. Phycol., 46: 1161-1171

Poulson-Ellestad, K. L., C. M. Jones, J. Roy, M. R. Viant, F. M. Fernández, J. Kubanek and B. L. Nunn 2014 Metabolomics and proteomics reveal impacts of chemically mediated competition on marine plankton. Proc. Natl. Acad. Sci. U.S.A., 111 9009-9014

Qiu, X., K. Mukai, Y. Shimasaki, M. Tsuyama, T. Matsubara, Y Nakajima, T. Honjo and Y. Oshima 2016 Potential maximum quantum yield of photosystem II reflects the growth rate of Chattonella marina in field bloom samples. J. Fac. Agr. Kyushu Univ., 61: 331-335

Qiu, X., Y. Shimasaki, M. Tsuyama, T. Yamada, R. Kuwahara, M. Kawaguchi, M. Honda, H. Gunjikake, R. Tasmin and M. Shimizu 2013 Growth-phase dependent variation in photosynthetic activity and cellular protein expression profile in the harmful raphidophyte Chattonella antiqua. Biosci. Biotechnol. Biochem., 77: 46-52

Tiffany, M. A., S. B. Barlow, V. E. Matey and S. H. Hurlbert 2001 Chattonella marina (Raphidophyceae), a potentially toxic alga in the Salton Sea, California. In Saline Lakes, Springer, 187-194

Trost, P., S. Fermani, L. Marri, M. Zaffagnini, G. Falini, S. Scagliarini, P. Pupillo and F. Sparla 2006 Thioredoxindependent regulation of photosynthetic glyceraldehyde-3phosphate dehydrogenase: autonomous vs. CP12-dependent mechanisms. Photosyn. Res., 89: 263-275

Wang, D.-Z., H. Zhang, Y. Zhang and S.-F. Zhang 2014 Marine dinoflagellate proteomics: current status and future perspectives. J. Proteomics, 105: 121-132

Warner, M. E. and M. L. Madden 2007 The impact of shifts to elevated irradiance on the growth and photochemical activity of the harmful algae Chattonella subsalsa and Prorocentrum minimum from Delaware. Harmful Algae, 6: 332-342

Watanabe, M., K. Kohata and T. Kimura 1991 Diel vertical migration and nocturnal uptake of nutrients by Chattonella antiqua under stable stratification. Limnol. Oceanogr., 36 593-602

Wood, Z. A., L. B. Poole and P. A. Karplus 2003 Peroxiredoxin evolution and the regulation of hydrogen peroxide signaling. Science, 300: 650-653

Yamatogi, T., M. Sakaguchi, M. Iwataki and K. Matsuoka 2006 Effects of temperature and salinity on the growth of four harmful red tide flagellates occurring in Isahaya Bay in Ariake Sound, Japan. Nippon Suisan Gakk., 72: 160-168

Yang, Z.-K., Y.-H. Ma, J.-W. Zheng, W.-D. Yang, J.-S. Liu and H.-Y. Li 2014 Proteomics to reveal metabolic network shifts towards lipid accumulation following nitrogen deprivation in the diatom Phaeodactylum tricornutum. J. Appl. Phycol., 26: $73-82$ 